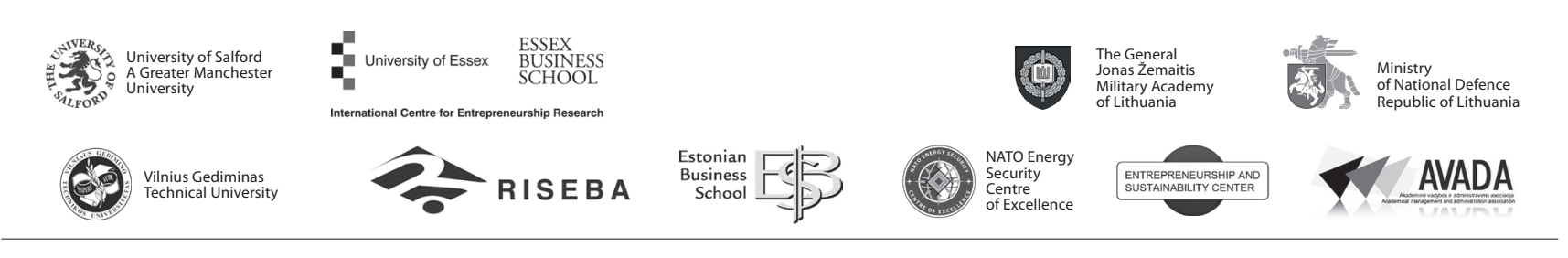

\author{
JOURNAL OF SECURITY AND SUSTAINABILITY ISSUES \\ ISSN 2029-7017 print/ISSN 2029-7025 online \\ 2017 December Volume 7 Number 2 \\ https://doi.org/10.9770/jssi.2017.7.2(12)
}

\title{
SUSTAINABLE DEVELOPMENT OF THE PROFESSIONAL COMPETENCIES OF UNIVERSITY STUDENTS: COMPARISON OF TWO SELECTED CASES FROM THE CZECH REPUBLIC
}

\author{
Jana Marie Šafránková1, Martin Šikýř̌ \\ ${ }^{1,2}$ College of Regional Development and Banking Institute - AMBIS, Narozni 2600/9, 15800 Praha 5, Czech Republic \\ E-mails: ${ }^{1}$ jana.safrankova@ambis.cz; ${ }^{2 m a r t i n . s i k y r @ a m b i s . c z ~}$
}

Received 22 February 2017; accepted 26 November 2017

\begin{abstract}
The goal of the paper is to summarize the results of the authors' questionnaire survey focused on identification and comparison of possible differences in study motivation and job expectations of students of one private and one public university in the Czech Republic to find out potential sources of students' dissatisfaction and to propose appropriate measures to improve the teaching process in order to achieve the sustainable development of the professional competencies of university students. The questionnaire survey was conducted by authors from February to April 2017. The respondents were full-time and combined bachelor's students of the College of Regional Development in Prague (private) and the Masaryk Institute of Advanced Studies of the Czech Technical University in Prague (public). The relevant data were obtained from 758 students. The data analysis was based on the calculation of relative frequencies (as a share from the total number of respondents) and the evaluation of the dependence of responses on the type of university (students of the private college and students of the public institute) using contingency tables and chi-square tests of independence. The results support the assumption that the current generation of university students studies to succeed in the future, but it has relatively high expectations about work and career that may reduce its employability if it does not have the appropriate work experience and social habits.
\end{abstract}

Keywords: higher education, university students, labour market, professional competencies, sustainable development, Czech Republic

Reference to this paper should be made as follows: Šafránková1, J. M.; Šikýř, M. 2017. Sustainable development of the professional competencies of university students: comparison of two selected cases from the Czech Republic, Journal of Security and Sustainability Issues 7(2): 321-333. https://doi.org/10.9770/jssi.2017.7.2(12)

JEL Classifications: I23, J21

\section{Introduction}

In the developed world, people with higher education are seen as the most important source and the greatest wealth that determine their future prosperity and sustained competitiveness (Kucharčíková, Koňušíková \& Tokarčíková 2016, p. 151; Oganisjana et al. 2017).

The higher education in most developed countries is focused on the development of professional competencies of young specialists in various professions (Figueiredo et al. 2017, p. 1401). The professional competencies (knowledge, skills and abilities) that enable people to successfully perform agreed work, achieve desired performance and meet expected objectives of the organization may be divided into technical (hard) and behavioural (soft) competencies (Armstrong \& Taylor 2014, p. 129). The technical (hard) competencies represent relevant professional knowledge, skills and abilities that people need to successfully perform their jobs. The behavioural (soft) competencies represent proper work and social habits as well as appropriate development potential and personal aspirations that people need to successfully work and grow in the organization. 
Through the system of higher education, young people are systematically prepared for a successful life and a professional career in the society (Tarlea 2017, p. 670). The higher education affects the employability and competitiveness of young people in the labour market (Attanasio \& Kaufmann 2017, p. 35). Young people with higher education also significantly increase their chances on the labour market to reach a satisfying and rewarding career. However, the competition among young people is strong and the requirements of employers are high (Konstantinovskiy 2017, p. 201). All these issues are part of the sustainable development of the society that also includes the sustainable development of the professional competencies of potential work force, especially young people, in this case university students and graduates.

A common problem of employing young people is that they lack relevant professional skills and social habits (Cordero-Cutillas, Huguet-Monfort \& Escribano-Tortajada 2011, p. 328; Dančišinová, et al., 2017, p. 38). Many young people of various specializations have better theoretical knowledge than practical experience (Stanciu \& Banciu 2012, p. 821). Some young people also have no real idea about their future career, but often require positions that do not match their abilities, just to get a job promising them high earnings and rapid career (Garcia-Arical \& Van der Velden 2008, p. 219).

Both theory and practice show that in the developed world the abilities, values and beliefs of today's young people different from those of their parents and grandparents and that in the case of next generations these differences will be more apparent (Horváthová \& Čopíková 2015, p. 217; Smoląg, et al., 2015, p 149). These facts are very important because today's young people will constitute about fifty percent of the workforce by 2020 (Barbuto \& Gottfredson 2016, p. 59) and because today's young people think of work and career differently than members of the older generation (Stewart et al. 2017, p. 45). It seems like a problem, but the truth is that every new generation brings new perspectives and approaches that are necessary for the future progress of the society.

Today's young people are greatly influenced by modern technologies and high standard of living (Yazici 2016, p. 291) and their general approach to life is also reflected in their approach to study, work and career. It is positive that many young people study to increase their chances on the labour market (Johnson et al. 2016, p. 193), but their professional and personal qualities often do not meet the requirements of organization (Kranov \& Khalaf 2017, p. 1079). On the other hand, many young people crave for meaning-full work, flexible hours, work-life balance, personal development, friendly relationships or career changes (Inanc \& Ozdilek 2016, p. 473). Therefore, most organizations tend to hire experienced workers than young people with inadequate experience and unreal expectations. This may lead to the potential unemployment among young people that seems to be a serious social and economic problem (Sirůček \& Pavelka 2013, p. 1279; Kot and Pigoń, 2014, p. 55).

From the perspective of sustainable employability of young people, in this case university students and graduates, the most important condition needed to succeed on the current labour market is the capability and motivation to learn and develop necessary professional knowledge, skills and abilities as well as suitable work and social habits. This applies to both the period of study and the period of employment. Therefore, it is important that both universities and employers contribute to the sustainable development of the professional competencies of university students and graduates to positively influence their abilities, values and beliefs. Universities should be able to provide students with relevant theoretical knowledge and practical applications, ideally in collaboration with potential employers. The higher education should be directed to the development of both professional and personal qualities of students. Employers should establish and maintain effective relationships with suitable universities to have a chance to meet, attract, and select talented young people and potential workers. Employers should also apply a positive approach to the employment of young people and focus on their strengths to utilize their potential. However, the success in the sustainable development of the professional competencies of university students and graduates is conditioned by their capability and motivation. University students and graduates must be ready to continually learn and develop necessary professional knowledge, skills and abilities. 


\section{Goal and method}

The goal of the paper is to summarize the results of the authors' questionnaire survey focused on identification and comparison of possible differences in study motivation and job expectations of students of one private and one public university in the Czech Republic to find out potential sources of students' dissatisfaction and to propose appropriate measures to improve the teaching process in order to achieve the sustainable development of the professional competencies of university students.

The questionnaire survey was conducted by authors from February to April 2017. The respondents were fulltime and combined bachelor's students of the College of Regional Development in Prague (private) and the Masaryk Institute of Advanced Studies of the Czech Technical University in Prague (public). The relevant data were obtained from 758 students. Students of the College of Regional Development in Prague studied Urban and Regional Development Management and Security and Safety Management in Regions. Students of the Masaryk Institute of Advanced Studies of the Czech Technical University in Prague studied Personnel Management in Industrial Enterprises and Management and Economy of an Industrial Enterprise. The difficulty of study in these bachelor's programmes is comparable. The essential difference lies in paying tuition fees and in taking entrance exams. Students of the College of Regional Development in Prague pay tuition fees, but do not take entrance exams. Students of the Masaryk Institute of Advanced Studies of the Czech Technical University in Prague do not pay tuition fees, but take entrance exams.

The questionnaire survey was based on the assumption that the current generation of university students studies to succeed in the future, but it has relatively high expectations about work and career that may reduce its employability if it does not have the appropriate work experience and social habits. The questionnaire included twelve multiple choice questions focused on university students' motivation to study at university and their expectations about the future career related to the sustainable development of their professional competencies: What reasons led you to study at university? Would you change your decision to study at university? How do you see the quality of teaching at the university? How would you characterize your interest in study at the university? Do you work during the academic year? Do you think that higher education give you more chances to succeed on the labour market? What abilities are the most important for the success on the labour market? Do you want to work in your place of residence? Would you like to be a manager? What do you expect in the field of work and career? How do you see your chances on the labour market? What monthly income do you expect after graduation?

The relevant data were obtained from 758 students, including 498 (66\%) students of the College of Regional Development in Prague (students of the private college) and 260 (34\%) students of the Masaryk Institute of Advanced Studies of the Czech Technical University in Prague (students of the public institute). The respondents were characterized by gender ( $31 \%$ male, $69 \%$ female), age ( $71 \% 29$ years or less, $29 \% 30$ years or more), and form of study ( $69 \%$ full-time, $31 \%$ combined).

The data analysis was based on the calculation of relative frequencies (as a share from the total number of students of the private college and students of the public institute) and the evaluation of the dependence of responses on the type of university (students of the private college and students of the public institute) using contingency tables and chi-square tests of independence. Chi-square tests of independence were applied to determine whether responses of respondents expressed in contingency tables were related to age of respondents (students aged 29 or less and students aged 30 or more). The test procedure included the following steps: (1) formulation of null $\left(\mathrm{H}_{0}\right)$ and alternative $\left(\mathrm{H}_{\mathrm{A}}\right)$ hypothesis, (2) selection of a level of significance $\alpha$, (3) calculation of the chi square statistic $\chi^{2}$, (4) calculation of the degrees of freedom $\mathrm{f}$, (5) selection of the critical chisquare value $\chi_{\alpha}^{2}(\mathrm{f})$, and (6) comparison of the chi square statistic $\chi^{2}$ to the critical chi-square value $\chi_{\alpha}^{2}(\mathrm{f})$ and acceptation or rejection of the null hypothesis. 


\section{Results and discussion}

The results of the authors' research cooperation and questionnaire survey are summarized and discussed in four parts, focusing on the higher education in the Czech Republic, the motivation of students to study at university, the expectations of students about the future career, and the related challenges of employing young people. All these four parts are relevant to the achievement of the sustainable development of the professional competencies of university students. Although the current survey results do not allow authors to draw general conclusions, they confirm main findings of earlier studies cited in the paper and they show some interesting tendencies in the students' attitudes to study, work and career that are worth attention both from the point of view of universities and from the point of view of employers and their current approach to the employment of young people.

\subsection{Higher education in the Czech Republic}

The base of the sustainable development of the society and its human resources is the system of education, in this case the system of higher education. According to the data of the Ministry of Education, Youth and Sports of the Czech Republic (MEYS 2017a), by June 30, 2017, there were 26 public and 44 private universities in the Czech Republic that offer higher education in various fields of study. In accordance with the European system of higher education, the system of higher education in the Czech Republic consists of three levels - Bachelor's (3-4 years), Master's (2-3 years) and Doctoral (3-5 years) degree programmes. Bachelor's degree programmes constitute the first level of higher education and successful graduates may enter the labour market or continue their studies in master's programmes in related fields. Master's degree programmes are intended to provide theoretical knowledge and develop skills for creative and scientific activities. Doctoral degree programmes are intended for graduates from Master's degree programmes and are focused on scientific and research activities. Most of the private universities offer higher education mainly in economic, humanities and social sciences on bachelor's and master's levels.

In terms of the number of students of public and private universities in the Czech Republic, the figure 1 shows the total number of students of public universities and the number of students of technical, economic, humanities and social sciences at public universities in the Czech Republic from 2001 to 2016.

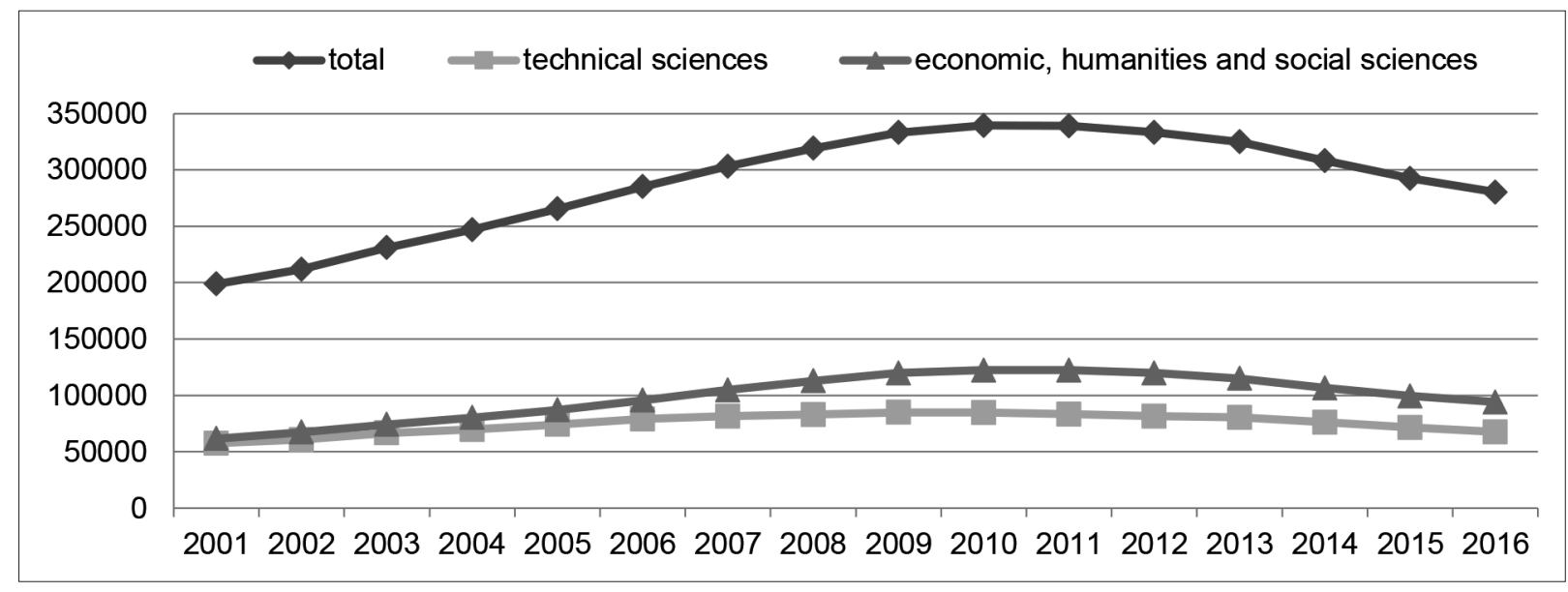

Fig. 1. The number of students of public universities in the Czech Republic

Source: authors based on the data of the Ministry of Education, Youth and Sports of the Czech Republic (MEYS 2017b)

The figure 2 shows the total number of students of private universities and the number of students of technical, economic, humanities and social sciences at private universities in the Czech Republic from 2001 to 2016. 


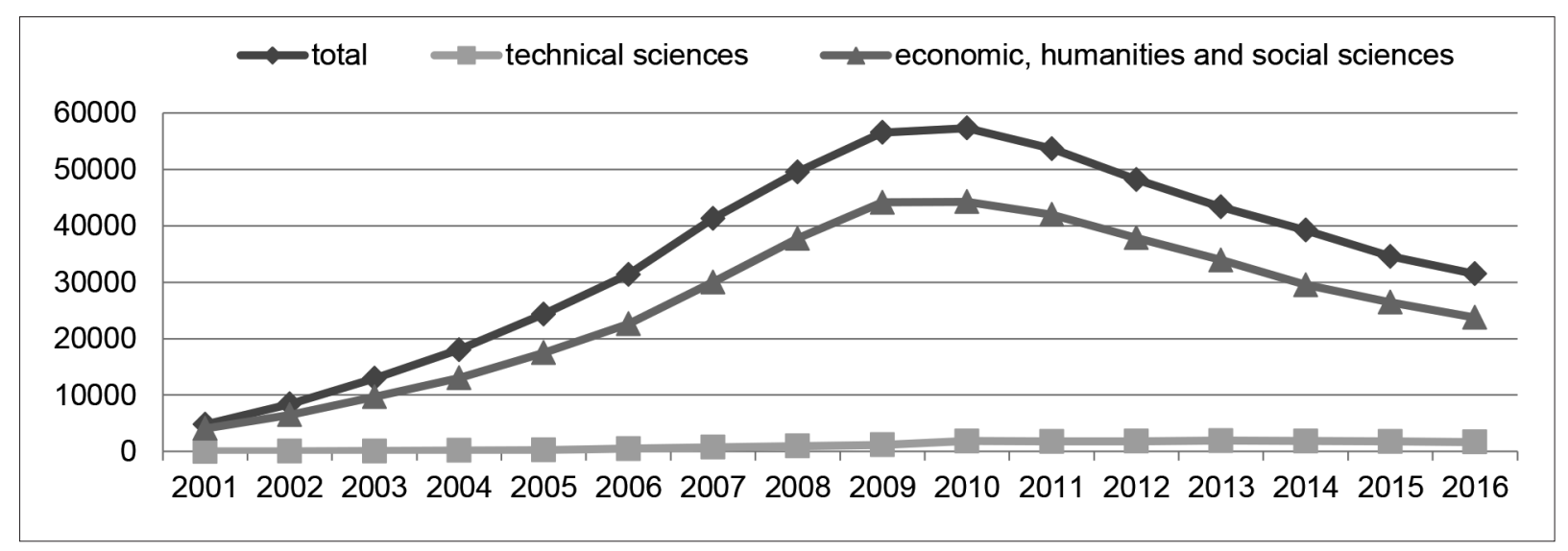

Fig. 2. The number of students of private universities in the Czech Republic

Source: authors based on the data of the Ministry of Education, Youth and Sports of the Czech Republic (MEYS 2017b)

The data in figures 1 a 2 show that the number of students of economic, humanities and social sciences is generally and consistently higher than the number of students of technical sciences and that the difference is more pronounced in private universities. This is one of the unsustainable problems for the future sustainable development of the labour market. The prevailing number of private universities and students of economic, humanities and social sciences in the Czech Republic raises questions about the quality of private universities and professional and personal qualities of students of economic, humanities and social sciences, especially in relation to the needs of the labour market and the requirements of employers.

\subsection{Students' motivation to study at university}

From the perspective of sustainable employability of young people, the most important condition needed to succeed on the current labour market is the capability and motivation to learn and develop necessary professional knowledge, skills and abilities as well as suitable work and social habits.

According to the authors' survey results, students of the private college stated that they are motivated to study at university by an effort to increase their chances on the labour market (61\%), by an effort to obtain the university degree $(60 \%)$ or by the possibility of higher earnings $(47 \%)$ and students of the public institute stated that they are motivated to study at university by an effort to increase their chances on the labour market (79\%), by an effort to obtain the university degree $(62 \%)$ or by the possibility of higher earnings $(60 \%)$. In this context, $94 \%$ of students of the private college and $88 \%$ of students of the public institute agreed that higher education gives them more chances to succeed on the labour market. On the other hand, $74 \%$ of students of the private college and $75 \%$ of students of the public institute stated that they see their chances on the labour market as medium. They were afraid of the strong competition and the lack of work experience. The data analysis showed a significant difference between students of the private college and students of the public institute $(\mathrm{p}<0.05)$. We tested the null hypothesis that there is no difference between students of the private college and students of the public institute regarding the evaluation of their chances on the labour market (table 1). Since the chi square statistic $\chi^{2}$ was greater than the critical chi-square value $\chi_{0.05}^{2}$ (2) we rejected the null hypothesis in favour of the alternative hypothesis. There was a difference between students of the private college and students of the public institute regarding the evaluation of their chances on the labour market. 
Table 1. Contingency table. Question: "How do you see your chances on the labour market?"

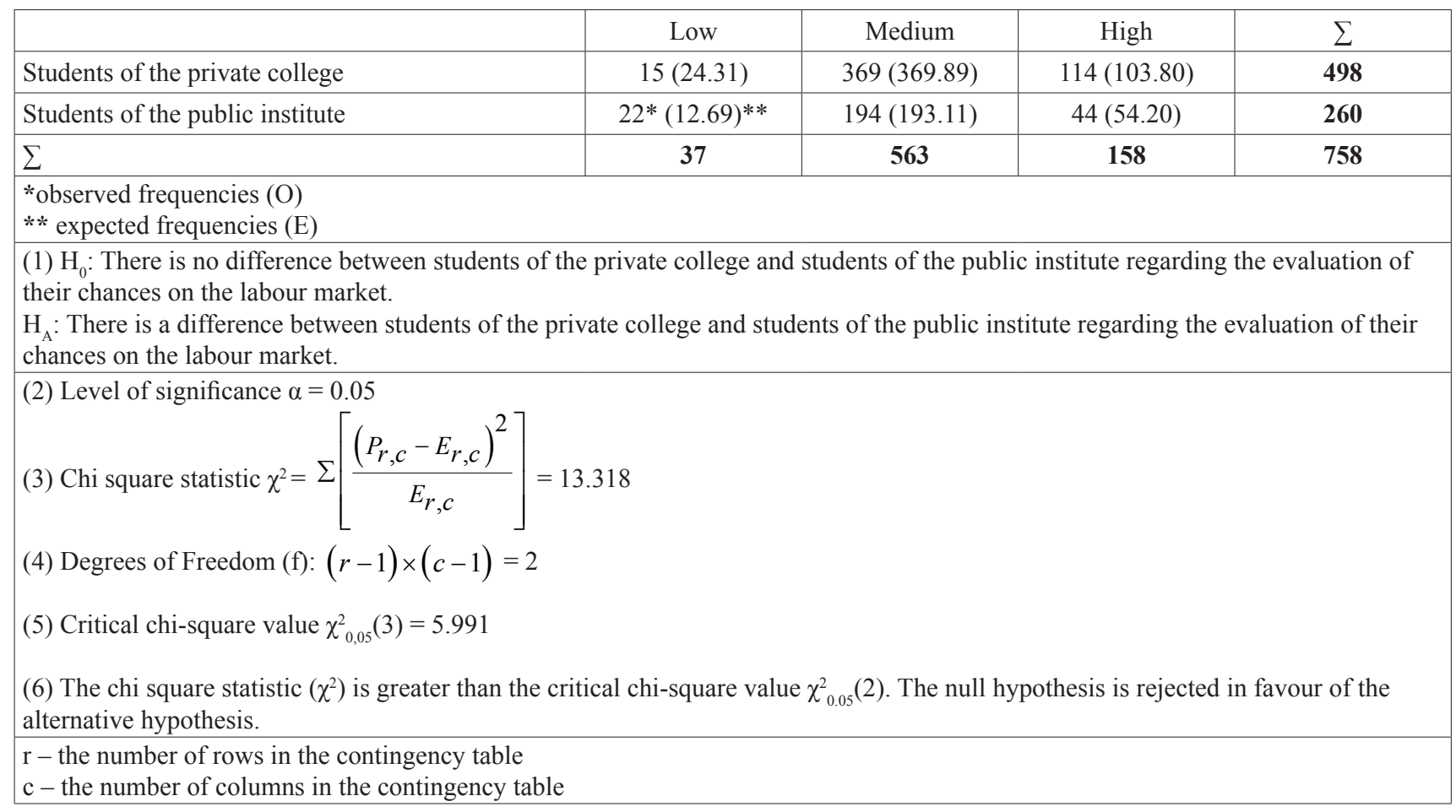

Source: authors

The feeling of the lack of work experience can affect the interest of students in studying. 53\% of students of the private college and $52 \%$ of students of the public institute stated that they are interested in the selected field of study, but it does not meet their expectations. Students complained of theoretical subjects without obvious connections and practical applications. $73 \%$ of students of the private college and $61 \%$ of students of the public institute stated that the quality of teaching at the university is medium. The data analysis showed a significant difference between students of the private college and students of the public institute $(p<0.05)$. We tested the null hypothesis that there is no difference between students of the private college and students of the public institute regarding the evaluation of the quality of teaching at the university (table 2). Since the chi square statistic $\chi 2$ was greater than the critical chi-square value $\chi_{0.05}^{2}(2)$ we rejected the null hypothesis in favour of the alternative hypothesis. There was a difference between students of the private college and students of the public institute regarding the evaluation of the quality of teaching at the university.

The general dissatisfaction with the quality of teaching can reduce the motivation of students to study. The attendance of students is generally poor. Students do not attend the university to learn something new, but to take the test or pass the exam. Many students go to work rather than to school. On the one hand, they can earn money and get experience, but on the other hand, it is not easy for them to study and work at the same time. Students do not focus on their study because of their work. This is a big challenge for universities to change the attitude of students. Universities should be able to persuade students that the adoption of theoretical knowledge is important, but at the same time they should be able to provide students with enough practical applications, ideally in collaboration with potential employers. The higher education should be directed to the development of both professional and personal qualities of students, who must gain relevant theoretical knowledge, practical skills and social habits. 
Table 2. Contingency table. Question: "How do you see the quality of teaching at the university?"

\begin{tabular}{|c|c|c|c|c|}
\hline & Low & Medium & High & $\sum$ \\
\hline Students of the private college & $36^{*}(84.75)^{* *}$ & $362(342.29)$ & $100(70.96)$ & 498 \\
\hline Students of the public institute & $93(44.25)$ & $159(178.29)$ & $8(37.04)$ & 260 \\
\hline$\sum$ & 129 & 521 & 108 & 758 \\
\hline \multicolumn{5}{|l|}{$\begin{array}{l}* \text { observed frequencies }(\mathrm{O}) \\
* * \text { expected frequencies }(\mathrm{E})\end{array}$} \\
\hline \multicolumn{5}{|c|}{$\begin{array}{l}\text { (1) } \mathrm{H}_{0} \text { : There is no difference between students of the private college and students of the public institute regarding the evaluation of } \\
\text { the quality of teaching at the university. } \\
\mathrm{H}_{\mathrm{A}} \text { : There is a difference between students of the private college and students of the public institute regarding the evaluation of the } \\
\text { quality of teaching at the university. }\end{array}$} \\
\hline \multicolumn{5}{|c|}{$\begin{array}{l}\text { (2) Level of significance } \alpha=0.05 \\
\text { (3) Chi square statistic } \chi^{2}=\Sigma\left[\frac{\left(P_{r, c}-E_{r, c}\right)^{2}}{E_{r, c}}\right]=119.728\end{array}$} \\
\hline \multicolumn{5}{|c|}{ (4) Degrees of Freedom (f): $(r-1) \times(c-1)=2$} \\
\hline \multicolumn{5}{|c|}{ (5) Critical chi-square value $\chi_{0,05}^{2}(3)=5.991$} \\
\hline \multicolumn{5}{|c|}{$\begin{array}{l}\text { (6) The chi square statistic }\left(\chi^{2}\right) \text { is greater than the critical chi-square value } \chi_{0.05}^{2}(2) \text {. The null hypothesis is rejected in favour of the } \\
\text { alternative hypothesis. }\end{array}$} \\
\hline $\begin{array}{l}\mathrm{r}-\text { the number of rows in the } \mathrm{c} \\
\mathrm{c}-\text { the number of columns in } \mathrm{tl}\end{array}$ & $\begin{array}{l}\text { table } \\
\text { ency table }\end{array}$ & & & \\
\hline
\end{tabular}

Source: authors

$87 \%$ of students of the private college and $84 \%$ of students of the public institute stated that they work during the academic year to earn money and get experience, but only $22 \%$ of students of the private college and $20 \%$ of students of the public institute stated that they work in the field of study, which may be the problem. Of course, every work experience is good to get needed work and social habits, but working outside the field of study does not develop professional knowledge, skills and abilities needed to find a job in the field of study. The data analysis showed no significant difference between students of the private college and students of the public institute.

\subsection{Students' expectations about the future career}

Students' expectations about the future career indicate the future expected situation on the labour market and reveals possible problems with sustainable employability of the potential workforce. From the perspective of today's common job requirements, suitable job applicants should demonstrate relevant professional knowledge, skills and abilities, suitable work and social habits, and appropriate development potential and personal aspirations for successful performance, professional growth and career advancement. Although many young people do not meet the common job requirements, their expectations about the future career are relatively high. According to the authors' survey results, the students' expectations about the future career included meaningful work, self-fulfilment, friendly team, fair wages, favourable environment, job security, professional management, personal development, employee benefits or career prospects.

Many young people do not want to start from scratch, overestimate themselves and require positions that do not match their abilities. For example, according to the authors' survey results, $59 \%$ of students of the private college and $71 \%$ of students of the public institute stated that they want to be managers (manage people), which is normal when they study to become managers, but they forget that it is a long way and that they have a lot to learn. The data analysis showed a significant difference between students of the private college and students of the public institute $(\mathrm{p}<0.05)$. We tested the null hypothesis that there is no difference between students of the private college and students of the public institute regarding the wish to be a manager (table 3 ). Since the chi square statistic $\chi^{2}$ was greater than the critical chi-square value $\chi_{0.05}^{2}(2)$ we rejected the null hypothesis in favour 
of the alternative hypothesis. There was a difference between students of the private college and students of the public institute regarding the wish to be a manager.

Table 3. Contingency table. Question: "Would you like to be a manager?"

\begin{tabular}{|c|c|c|c|c|}
\hline & Yes & No & Do not know yet & $\sum$ \\
\hline Students of the private college & $294 *(314.70) * *$ & $51(44.68)$ & $153(138.63)$ & 498 \\
\hline Students of the public institute & $185(164.30)$ & $17(23.32)$ & $58(72.37)$ & 260 \\
\hline$\sum$ & 479 & 68 & 211 & 758 \\
\hline \multicolumn{5}{|l|}{$\begin{array}{l}\text { *observed frequencies }(\mathrm{O}) \\
* * \text { expected frequencies }(\mathrm{E})\end{array}$} \\
\hline \multicolumn{5}{|c|}{$\begin{array}{l}\text { (1) } \mathrm{H}_{0} \text { : There is no difference between students of the private college and students of the public institute regarding the wish to b } \\
\text { manager. } \\
\mathrm{H}_{\mathrm{A}} \text { : There is a difference between students of the private college and students of the public institute regarding the wish to be a } \\
\text { manager. }\end{array}$} \\
\hline
\end{tabular}

(2) Level of significance $\alpha=0.05$

(3) Chi square statistic $\chi^{2}=\Sigma\left[\frac{\left(P_{r, c}-E_{r, c}\right)^{2}}{E_{r, c}}\right]=119.728$

(4) Degrees of Freedom (f): $(r-1) \times(c-1)=2$

(5) Critical chi-square value $\chi_{0,05}^{2}(3)=5.991$

(6) The chi square statistic $\left(\chi^{2}\right)$ is greater than the critical chi-square value $\chi_{0.05}^{2}(2)$. The null hypothesis is rejected in favour of the alternative hypothesis.

$\mathrm{r}-$ the number of rows in the contingency table

$\mathrm{c}-$ the number of columns in the contingency table

Source: authors

A specific problem of many people (young and old) is unwillingness to commute to work. According to the authors' survey results, $46 \%$ of students of the private college and $45 \%$ of students of the public institute stated that they want to work in their place of residence, $40 \%$ of students of the private college and $35 \%$ of students of the public institute stated that they are willing to commute to work, and $14 \%$ of students of the private college and $20 \%$ of students of the public institute stated that they are willing to move for work. The data analysis showed no significant difference between students aged 29 or less and students aged 30 or more.

When it comes to wage expectations, the starting expectations of many young people are usually higher than the real wage that an employer can offer to a newcomer with the lack of relevant work experience. According to the authors' survey results, $47 \%$ of students of the private college and $60 \%$ of students of the public institute stated that they are motivated to study at university by the possibility of higher earnings and $43 \%$ of students of the private college and $63 \%$ of students of the public institute stated that after graduation they expect the monthly income between EUR 750 and EUR 1,050. According to the data of the data of the Czech Statistical Office (CZSO 2017), in Q2 2017, the average gross monthly nominal wage was approximately EUR 1,107 (CZK 29,346). The data analysis showed a significant difference between students of the private college and students of the public institute $(\mathrm{p}<0.05)$. We tested the null hypothesis that there is no difference between students of the private college and students of the public institute regarding expected monthly income after graduation (table 4$)$. Since the chi square statistic $\left(\chi^{2}\right)$ was greater than the critical chi-square value $\left(\chi_{0.05}^{2}\right)$ we rejected the null hypothesis in favour of the alternative hypothesis. There was a difference between students of the private college and students of the public institute regarding expected monthly income after graduation. 
Table 4. Contingency table. Question: "What monthly income do you expect after graduation?"

\begin{tabular}{|c|c|c|c|c|}
\hline EUR 700 and less & EUR 750-1,050 & EUR $1,100-1,450$ & $\begin{array}{l}\text { EUR } 1,500 \\
\text { and more }\end{array}$ & $\sum$ \\
\hline $\begin{array}{l}\text { Students of the } \\
\text { private college }\end{array}$ & $213(247.03)$ & $159(129.43)$ & $90(72.27)$ & 498 \\
\hline $\begin{array}{l}\text { Students of the } \\
\text { public institute }\end{array}$ & $163(128.97)$ & 38 (67.57) & $20(37.73)$ & 260 \\
\hline 75 & 376 & 197 & 110 & 758 \\
\hline \multicolumn{5}{|c|}{$\begin{array}{l}* \text { observed frequencies }(\mathrm{O}) \\
* * \text { expected frequencies }(\mathrm{E})\end{array}$} \\
\hline \multicolumn{5}{|c|}{$\begin{array}{l}\text { (1) } \mathrm{H}_{0} \text { : There is no difference between students of the private college and students of the public institute regarding expected monthly } \\
\text { income after graduation. } \\
\mathrm{H}_{\mathrm{A}} \text { : There is a difference between students of the private college and students of the public institute regarding expected monthly } \\
\text { income after graduation. }\end{array}$} \\
\hline \multicolumn{5}{|l|}{ (3) Chi square statistic $\chi^{2}=\Sigma\left[\frac{\left(P_{r, c}-E_{r, c}\right)^{2}}{E_{r, c}}\right.$} \\
\hline \multicolumn{5}{|l|}{ (4) Degrees of Freedom (f): $(r-1) \times(c-1)=3$} \\
\hline \multicolumn{5}{|l|}{ (5) Critical chi-square value $\chi_{0,05}^{2}(3)=7.815$} \\
\hline \multicolumn{5}{|c|}{$\begin{array}{l}\text { (6) The chi square statistic }\left(\chi^{2}\right) \text { is greater than the critical chi-square value } \chi_{0.05}^{2}(3) \text {. The null hypothesis is rejected in favour of the } \\
\text { alternative hypothesis. }\end{array}$} \\
\hline $\begin{array}{l}r-\text { the number of rows in the contingency tab } \\
c-\text { the number of columns in the contingency }\end{array}$ & & & & \\
\hline
\end{tabular}

Source: author

Despite all the expectations and problems, all students were aware of the fact that the success on the labour market is determined by their abilities. According to students, the most important abilities necessary for the success on the labour market include the ability to communicate with people, the ability to solve problems, the ability to acquire new knowledge, the ability of team work or the ability to apply own knowledge. Generally, students should continually improve their knowledge of foreign languages, their computer skills or their knowledge of management, economics, psychology, sociology, marketing, informatics or law.

\subsection{Challenges of employing young people}

Many employers value experienced workers as the most important source in their organizations. Employers require and appreciate workers with relevant professional knowledge, skills and abilities. It seems reasonable, but from the perspective of potential shortage of qualified and motivated people on the Czech labour market, this does not seem to be a sustainable approach. Employers should apply a positive approach to the employment of young people and focus on their strengths, not weaknesses.

Subjectively employers are afraid of organizational and performance problems of employing young people that usually do not meet their requirements for professional skills and experience, as well as for social behaviour and professional motivation (Němec \& Surynek 2015, p. 1180), but objectively employers have lack of effective strategies, policies and practices of employing young people as well as lack of understanding of their specific needs (Grenčíková \& Španková 2016, p. 158). To deal with the potential shortage of people with appropriate technical and behavioural competencies on today's Czech labour market, employers should learn how to create appropriate and attractive employment opportunities for young people and how to effectively develop their potential. In other words, the young generation entering the labour market make employers change their HR strategies, policies and practices and employers must learn to effectively attract, employ and develop young workers, whose expectations about work and career are different from those of their older colleagues and man- 
agers. If employers want to compete for and retain top young workers, they must make themselves attractive to them (Barbuto \& Gottfredson 2016, p. 59).

Employers should establish and maintain effective relationships with suitable secondary schools and universities to have a chance to meet, attract, and select talented young people and potential workers. An attractive employee value proposition should include meaningful work, flexible hours, friendly relationships, personal development or career prospects. People with a talent that cannot be easily copied by competitors represent a competitive advantage of the organization (Rofaida 2016, p. 615). Therefore, it is important for employers to create motivating working conditions for people to encourage the application and development of their individual knowledge, skills and abilities (Ingram 2016, p. 443).

Employers should also create age diverse groups of people to mix the new ideas of young people with the life and work experience of other people in the organization. This approach should allow employers to understand the needs and perspectives of different groups of people to create appropriate and attractive employment opportunities for them. The aim should be to gain a competitive advantage by employing people of all ages, but it requires changing some stereotypes associated with the employment of young people. In addition, many young people believe that the age alone is a barrier for getting a job, but the fact is that age diverse groups of people have various knowledge, skills and abilities that add value to the workplace and play a key role in achieving success of the organization.

On the other hand, young people should be ready to continually learn and develop necessary technical and behavioural competencies needed to succeed on the labour market. These competencies include knowledge of foreign languages or information technologies, as well as the knowledge of management, economics, psychology, sociology, marketing, informatics and law or the ability to communicate with people, to solve problems, to apply own knowledge or to collaborate and communicate with others.

\section{Conclusions}

The authors' survey results support the assumption that the current generation of university students studies to succeed in the future, but it has relatively high expectations about work and career that may reduce its employability if it does not have the appropriate work experience and social habits.

The authors' survey results include answers of 758 students, including 498 students of the College of Regional Development in Prague (students of the private college) and 260 students of the Masaryk Institute of Advanced Studies of the Czech Technical University in Prague (students of the public institute), focused on their motivation to study at university and their expectations about the future career. Although the current survey results do not allow authors to draw general conclusions, they confirm main findings of earlier studies cited in the paper and they show some interesting tendencies in the students' attitudes to study, work and career that are worth attention both from the point of view of universities and from the point of view of employers and their current approach to the employment of young people.

$61 \%$ of students of the private college and $79 \%$ of students of the public institute stated that they are motivated to study at university by an effort to increase their chances on the labour market, but $74 \%$ of students of the private college and $75 \%$ of students of the public institute stated that they see their chances on the labour market as medium. They were afraid of the strong competition and the lack of work experience. The data analysis showed a significant difference between students of the private college and students of the public institute.

$87 \%$ of students of the private college and $84 \%$ of students of the public institute stated that they work during the academic year to earn money and get experience, but only $22 \%$ of students of the private college and $20 \%$ of students of the public institute stated that they work in the field of study. The data analysis showed no significant difference between students of the private college and students of the public institute. 
$46 \%$ of students of the private college and $45 \%$ of students of the public institute stated that they want to work in their place of residence and the data analysis showed no significant difference between students aged 29 or less and students aged 30 or more.

$47 \%$ of students of the private college and $60 \%$ of students of the public institute stated that they are motivated to study at university by the possibility of higher earnings and $43 \%$ of students of the private college and $63 \%$ of students of the public institute stated that after graduation they expect the monthly income between EUR 750 and EUR 1,050. The data analysis showed a significant difference between students of the private college and students of the public institute.

The other students' expectations about the future career included meaningful work, self-fulfilment, friendly team, fair wages, favourable environment, job security, professional management, personal development, employee benefits or career prospects. This all can lead to the fact that most employers tend to hire experienced workers than young people with inadequate experience and unreal expectations.

Many employers value experienced workers as the most important source in their organizations. Employers require and appreciate workers with relevant professional knowledge, skills and abilities. It seems reasonable, but from the perspective of potential shortage of qualified and motivated people on the Czech labour market, this does not seem to be a sustainable approach. Employers should apply a positive approach to the employment of young people and focus on their strengths, not weaknesses. To deal with the potential shortage of people with appropriate technical and behavioural competencies on today's Czech labour market, employers should learn how to create appropriate and attractive employment opportunities for young people and how to effectively develop their potential.

Employers should establish and maintain effective relationships with suitable secondary schools and universities to have a chance to meet, attract, and select talented young people and potential workers. Employers should also create age diverse groups of people to mix the new ideas of young people with the life and work experience of other people in the organization.

On the other hand, young people should be ready to continually learn and develop necessary knowledge of foreign languages or information technologies, as well as the knowledge of management, economics, psychology, sociology, marketing, informatics and law or the ability to communicate with people, to solve problems, to apply own knowledge or to collaborate and communicate with others.

These issues open up new possibilities for further research focused on the labour market and employability of the new generation of work force.

\section{References}

Armstrong, M.; Taylor, S. 2014. Armstrong's Handbook of Human Resource Management Practice. 13th ed. London: Kogan Page Limited.

Attanasio, O. P.; Kaufmann, K. M. 2017. Education Choices and Returns on the Labor and Marriage Markets: Evidence from Data on Subjective Expectations, Journal of Economic Behavior and Organization, 140, 35-55. https://doi.org/10.1016/j.jebo.2017.05.002

Cordero-Cutillas, I.; Huguet-Monfort, J.; Escribano-Tortajada, P. 2011. Labour Market Access of Graduates in Law: Teaching and Learning of Skills and Abilities in the European Higher Education Area. 5th International Technology, Education and Development Conference, Ed. by Chova, L. G.; Torres, I. C.; Martinez, A. L. 328-332.

Barbuto, J. E.; Gottfredson, R. K. 2016. Human Capital, the Millennial's Reign, and the Need for Servant Leadership, Journal of Leadership Studies 10(2), 59-63. http://dx.doi.org/10.1002/j1s.21474

CZSO 2017. Average wages - Q 2 2017. The Czech Statistical Office. Available on the Internet: https://www.czso.cz/csu/czso/ cri/ prumerne-mzdy-2-ctvrtleti-2017 
Dančišinová, L., Benková, E., Daňková, Z. 2017. Presentation skills as important managerial competences in the context of professional communication Polish Journal of Management Studies, 15 (2), 37-46. https://doi.org/10.17512/pjms.2017.15.2.04

Figueiredo, H.; Biscaia, R.; Rocha, V.; Teixeira, P. 2017. Should we Start Worrying? Mass Higher Education, Skill demand and the Increasingly Complex Landscape of Young Graduates' Employment, Studies in Higher Education, 42(8), 1401-1420. http://dx.doi.org $/ 10.1080 / 03075079.2015 .1101754$

Garcia-Aracil, A.; Van Der Velden, R. 2008. Competencies for Young European Higher Education Graduates: Labor Market Mismatches and Their Payoffs, Higher Education, 55(2), 219-239. http://dx.doi.org/10.1007/s10734-006-9050-4

Grenčíková, A.; Špánková, J. 2016. Labour Migration Trends in the Slovak Republic, Economics and Sociology, 9(2), 158-167. http:// dx.doi.org/10.14254/2071-789X.2016/9-2/11

Horváthová, P.; Čopíková, A. 2015. Generation Y and its Impact on the Performance of Personnel Activities. 15th International Scientific Conference on Globalization and its Socio-Economic Consequences, Ed. by Kliestik, T., 217-223.

Inanc, E. E.; Ozdilek, E. 2016. Work Values as Predictors of Boundaryless Career Attitudes of Generation Y Turkish Higher Education Students. 3rd International Conference on Education and Social Sciences, Ed. by Uslu, F., 473-482.

Ingram, T. 2016. Relationships between Talent Management and Organizational Performance: The Role of Climate for Creativity. 8th International Scientific ENTRE Conference on Advancing Research in Entrepreneurship in the Global Context. Ed. By Wach, K.; Zur, A., 443-452.

Johnson, C. L.; Gutter, M., Xu, Y.; Cho, S. H.; DeVaney, S. 2016. Perceived Value of College as an Investment in Human and Social Capital: Views of generations X and Y, Family \& Consumer Sciences Research Journal 42(2), 193-207. http://dx.doi.org/10.1111/ fcsr. 12195

Konstantinovskiy, D. L. 2017. Expansion of Higher Education and Consequences for Social Inequality (the Case of Russia), Higher Education, 74(2), 201-220. http://dx.doi.org/10.1007/s10734-016-0043-7

Kot, S., Pigoń, Ł. 2014. Effective occupational counselling for the unemployed. Polish Journal of Management Studies, 10 (1), 54-62.

Kranov, A. A.; Khalaf, K. 2017. Work in Progress: Investigating the Employment Gap: What Employers Want from Engineering Graduates. 8th IEEE Global Engineering Education Conference, EDUCON 2017, 1097-1100.

Kucharčíková, A.; Koňušíková, L'; Tokarčíková, E. 2015. The Quantification of Human Capital Value in Digital Marketing Companies. International Scientific Conference Marketing Identity 2015: Digital Life. Ed by Čábyová, L'.; Petranová, D., 151-163.

MEYS 2017a. Universities. The Ministry of Education, Youth and Sports of the Czech Republic. Available on the Internet: http://www. msmt.cz/ministerstvo/odkazy/vysoke-skoly ?lang=1

MEYS 2017b. Data on students and graduates 2000-2016. The Ministry of Education, Youth and Sports of the Czech Republic. Available on the Internet: http://www.msmt.cz/ vzdelavani/skolstvi-v-cr/statistika-skolstvi/data-o-studentech-poprve-zapsanych-a-absolventechvysokych

Němec, O.; Surynek, A. 2015. Age Management as a Part of Corporate Social Responsibility. The 9th International Days of Statistics and Economics. Ed by Loster, T.; Pavelka, T., 1180-1190.

Oganisjana, K.; Svirina, A.; Surikova, S.; Grīnberga-Zālīte, G.; Kozlovskis, K. 2017. Engaging universities in social innovation research for understanding sustainability issues, Entrepreneurship and Sustainability Issues 5(1): 9-22. https://doi.org/10.9770/jesi.2017.5.1(1)

Rofaida, R. 2016. Competitive Advantage through Talent Management. 1st UPI Global Conference on Business, Management and Entrepreneurship. Ed by Abdullah, A. G.; Hurriyati, R.; Nandiyanto, A. et al., 615-617.

Smoląg, K., Kot, S., Oane-Marinescu, C.M. 2015. Contemporary conditions of engineers' education process management. Polish Journal of Management Studies, 11 (2), 149-159.

Stanciu, S.; Banciu, V. 2012. Quality of Higher Education in Romania: Are Graduates Prepared for the Labour Market? 3rd International Conference on Education and Educational Psychology. Ed by Bekirougullari, Z., 821-827.

Stewart, J. S.; Oliver, E. G.; Cravens, K. S.; Oishi, S. 2017. Managing Millennials: Embracing Generational Differences, Business Horizons, 60(1), 45-54. https://doi.org/10.1016/j.bushor.2016.08.011

Sirůček, P.; Pavelka, T. 2013. Youth Unemployment in the Czech Republic and the Impact of Economic Crisis. The 7th International Days of Statistics and Economics. Ed by Loster, T.; Pavelka, T., 1278-1287. 
Tarlea, S. 2017. Higher Education governance in Central and Eastern Europe: A Perspective on Hungary and Poland, European Educational Research Journal, 16(5), 670-683. http://dx.doi.org/10.1177/1474904116677756

Yazici, B. 2016. Attitudes of Generation Y toward Luxury Products and Youth-led Change in Luxury Consumption Behaviour, Turkish Online Journal of Design Art and Communication, 6(3), 291-306.

Jana Marie ŠAFRÁNKOVÁ is the Associate Professor and head of the Deparment of Management and Human Resources at the Institute of Regional Development and Banking Institute - AMBIS, Prague, Czech Republic. Her duties include pedagogical, publishing and research activities. Research interests: human resource, labour market, higher education, public administration, regional development.

Martin ŠIKÝ ̌́ is the Assistant Professor of the Deparment of Management and Human Resources at the Institute of Regional Development and Banking Institute - AMBIS, Prague, Czech Republic. His duties include pedagogical, publishing and research activities. Research interests: human resource, labour market, higher education, public administration, regional development.

Register for an ORCID ID:

https://orcid.org/register 